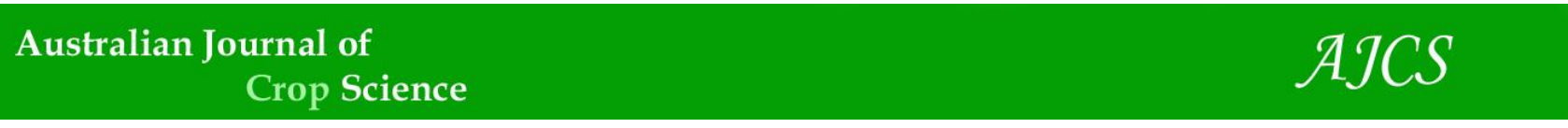

AJCS 14(10):1601-1607 (2020)

ISSN:1835-2707

doi: 10.21475/ajcs.20.14.10.p2388

\title{
Salinity management strategies and potassium fertilization in watermelon (Citrullus lanatus) cultivation
}

\author{
Saulo Soares da Silva ${ }^{1}$, Geovani Soares de Lima ${ }^{2}$, Vera Lúcia Antunes de Lima ${ }^{3}$, Hans Raj Gheyi ${ }^{3}$, Lauriane \\ Almeida dos Anjos Soares ${ }^{2}$, Rômulo Carantino Lucena Moreira ${ }^{1}$, Pedro Dantas Fernandes ${ }^{1}$, Elysson \\ Marcks Gonçalves Andrade ${ }^{1}$, Francisco Wesley Alves Pinheiro ${ }^{1}$
}

\author{
${ }^{1}$ Federal University of Campina Grande, Academic Unit of Agricultural Engineering, Campina Grande, 58.109-970, \\ Paraíba, Brazil \\ ${ }^{2}$ Federal University of Campina Grande, Academic Unit of Agrarian Sciences, Pombal, 58.840-000, Paraíba, Brazil \\ ${ }^{3}$ Federal University of Recôncavo of Bahia, Nucleus of Soil and Water Engineering, Cruz das Almas, 44.380-000, \\ Bahia, Brazil
}

*Corresponding author: geovanisoareslima@gmail.com

\begin{abstract}
This study aimed to evaluate the gas exchanges and growth of 'Sugar Baby' watermelon under different strategies of irrigation with saline water and potassium fertilization, in an experiment conducted in a protected environment. The experiment was conducted in randomized blocks, in $8 \times 3$ factorial arrangement, corresponding to eight water salinity management strategies applied at the phenological stages of the crop (NS = no stress along the cycle; $V E=$ salt stress during vegetative stage; $V E / F L=$ salt stress during vegetative and flowering stages; $F L=$ salt stress during flowering stage; $F L / F R=$ salt stress during flowering and fruiting stages; $F R=$ salt stress during fruiting stage; FR/MAT = salt stress during fruiting and maturation stages; MAT = salt stress during fruit maturation stage) and three potassium doses - KD (corresponding to 50, 100 and $150 \%$ of the recommendation), with three replicates. Two levels of water salinity were used, high and low values of electrical conductivity $\left(E C w=0.8\right.$ and $4.0 \mathrm{dS} \mathrm{m} \mathrm{m}^{-1}$ ) Watermelon growth and gas exchanges, especially transpiration, stomatal conductance, $\mathrm{CO}_{2}$ assimilation rate, instantaneous carboxylation efficiency, and absolute and relative growth rates of stem diameter were compromised by water salinity at the stages of flowering, fruiting and maturation. The potassium dose with $50 \%$ of $\mathrm{K}_{2} \mathrm{O}$ recommendation can be used in the cultivation of watermelon, without negatively affecting gas exchange and growth.
\end{abstract}

Keywords: Citrullus lanatus, salt stress, potassium, morphophysiology.

Abbreviations: $\mathrm{FC}$ field capacity; DAS_days after sowing; $g s$ stomatal conductance; $E_{-}$transpiration; $A_{-} \mathrm{CO}_{2}$ assimilation rate; Ci_internal $\mathrm{CO}_{2}$ concentration; WUEi_ instantaneous water use efficiency; $\mathrm{MBL}$ _branch length; $\mathrm{SD}$ _stem diameter; NL_number of leaves; RGR_relative growth rate; AGR_absolute growth rate; SV_Source of variation; SMS _Salinity management strategies; KD_ Potassium doses; DF_Degrees of freedom; CV_Coefficient of variation.

\section{Introduction}

Watermelon is a very important crop in Brazil and one of the most commercialized and cultivated in almost all Brazilian states, where its production corresponds to $10 \%$ of the total volume of vegetables produced in the country, being the second most exported horticultural crop. Additionally, this crop requires intensive labor, which generate income and jobs, contributing for local workers to remain in the rural areas and also providing economic return to the producer (Petry and Guimarães, 2013).

Watermelon is a glycophyte and has threshold salinity of 2.2 dS $\mathrm{m}^{-1}$ in the water (Ayers \& Westcot, 1999; Hoffman \& Shalhevet, 2007). As observed in other crops, the growth, physiology and production of watermelon are reduced when plants are irrigated using water with electrical conductivity higher than their salinity threshold. Nonetheless, its sensitivity may vary according to development stage and management practices. Some studies conducted with watermelon have shown that salinity reduces photosynthesis, transpiration, stomatal conductance and also affect the processes of absorption, transport, assimilation and distribution of nutrients, resulting in reductions of plant growth and yield (Figueirêdo et al., 2009; Furtado et al., 2012; Costa et al., 2013).

For providing favorable edaphoclimatic conditions to watermelon, the Northeast region of Brazil stands out as a region of expressive production of this crop (Moreira, et. al., 2015). However, there are many areas with low availability of good-quality water for irrigation, especially in semi-arid regions (Queiroz et al., 2016), so the use of saline water in irrigation becomes necessary (Neves et al., 2009). In spite of that, excess salts in the soil solution may cause nutritional imbalance, affecting the concentrations of nutrients in plants (Dong, 2012). The physiological and biochemical alterations occurring in plants under salt stress include reduction in water potential, cell dehydration, ionic cytotoxicity, reduction in cell/leaf expansion, and inhibition 
of cellular, metabolic and photosynthetic activities (Taiz et al., 2017).

Negative effects of salt stress on plants can be minimized by using strategies of water salinity management (Mesquita et al., 2015), which aim to contribute to the improvement in soil chemical, physical and biological conditions, reduction in the concentration and absorption of salts by plants, reduction in the impacts on the crops through cyclic use of sources of water with different salt concentrations at their phenological stages, and increase in land and water use efficiencies (Murtaza et al., 2006; Lacerda et al., 2011a). Several studies have demonstrated that the use of saline water at different development stages of common bean, tomato, melon, corn and cotton plants (Santos et al., 2005; Dias et al., 2011; Terceiro Neto et al., 2012; Calvet et al., 2013; Guedes et al., 2015; Soares et al., 2018) is a promising alternative to reduce the effects of salt stress on their growth, production and post-harvest quality and reduce the accumulation of salts in soil.

Another strategy is the use of chemical fertilization (Lacerda et al., 2016). Fertilization can minimize problems of salinity, especially using potassium (K), because higher $\mathrm{K}^{+} / \mathrm{Na}^{+}$ratio in plant tissues is considered an important indicator of salt tolerance. In addition, $\mathrm{K}$ plays an important role in the process of osmoregulation, especially in water saving, cell turgor and respiration. Therefore, fertilization with this macronutrient can be an option to reduce damage caused by the salts present in irrigation water because, in addition to being fundamental for osmotic regulation, it also makes water absorption possible (Langer et al., 2004; Shimazaki et al., 2007).

$\mathrm{K}$ accumulation is important for the maintenance of water in plants, performing important physiological functions, such as activation of enzymes, regulation of tissue turgor, stomatal opening and closing, control of $\mathrm{CO}_{2}$ concentration in substomatal chamber, photosynthesis, translocation of carbohydrates, synthesis of proteins, and it can also mitigate damage caused by salinity (Hawkesford et al., 2012). It is vital for photosynthesis, so that situations of deficiency cause reduction in the photosynthetic rate and increase in respiration; besides that, $\mathrm{K}$ favors the formation and translocation of carbohydrates, improving fruit quality (Araújo et al., 2012). In watermelon, $K$ is the nutrient absorbed in largest amounts by the plants and is the most efficient nutrient for fruit quality (Vidigal et al., 2009).

Therefore, the present study aimed to evaluate the effects of water salinity management strategies and potassium fertilization on the gas exchanges and growth of watermelon cv. 'Sugar Baby'.

\section{Results and discussion}

\section{Effect of salinity management strategies and potassium} fertilization on watermelon gas exchange

Salinity management strategies had significant effect ( $p<$ 0.01 ) on watermelon transpiration, stomatal conductance, $\mathrm{CO}_{2}$ assimilation rate and instantaneous carboxylation efficiency (Table 1). Potassium doses and their interaction with salinity management strategies had no significant influence $(p>0.05)$ on the gas exchanges of 'Sugar Baby' watermelon, at 55 days after sowing.

Watermelon transpiration rate was significantly influenced by the salinity management strategies and, according to the means comparison test (Fig $1 \mathrm{~A}$ ), plants under the strategies of no stress along the cycle (NS), salt stress during vegetative stage (VE), salt stress during vegetative and flowering stages $(\mathrm{VE} / \mathrm{FL})$, salt stress during flowering stage (FL) and salt stress during fruit maturation stage (MAT) had the highest mean values of $E$, of the order of 2.69, 2.78, 2.48, 2.58 and 2.29 $\mathrm{mmol}$ of $\mathrm{H}_{2} \mathrm{O} \mathrm{m}^{-2} \mathrm{~s}^{-1}$, respectively. Plants under the strategies $\mathrm{FL} / \mathrm{FR}, \mathrm{FR}$ and $\mathrm{FR} / \mathrm{MAT}$ obtained the lowest mean values of $E$, of the order of $1.88,1.64$ and $1.70 \mathrm{mmol}$ of $\mathrm{H}_{2} \mathrm{O} \mathrm{m}^{-2} \mathrm{~s}^{-1}$, which corresponded to reductions of $30.00,39.25$ and $37.03 \%$ compared to those under the strategy NS. Such decrease of transpiration in plants subjected to the strategies FL/FR, FR and FR/MAT possibly occurred due to the stomatal closure as a response to the osmotic stress caused by the irrigation water with highest $\mathrm{ECw}\left(4.0 \mathrm{dS} \mathrm{m}^{-1}\right)$, because the excess of salts in water and/or soil leads to alterations in plant physiological functions, inhibiting stomatal opening, which determines the reduction in leaf transpiration. The reduction in transpiration may have been due to the osmotic effect caused by irrigation water salinity, because high concentration of salts in soil compromises water absorption by roots, leading to reduction in stomatal opening to avoid water loss, thereby decreasing transpiration (Andrade et al., 2018).

As observed for transpiration, stomatal conductance was also significantly influenced by the salinity management strategies and, based on the means comparison test (Fig 1B), watermelon plants under the strategies NS, VE, VE/FL, FL and MAT had the highest mean values of $g s$, of the order of $0.17,0.19,0.16,0.17$ and $0.17 \mathrm{~mol} \mathrm{~m}^{-2} \mathrm{~s}^{-1}$, respectively. By contrast, plants subjected to the strategies FL/FR, FR and FR/MAT obtained the lowest mean values of $g s$, of the order of $0.10,0.09$ and $0.09 \mathrm{~mol} \mathrm{~m}^{-2} \mathrm{~s}^{-1}$, respectively, which corresponded to reductions of $41.18,47.06$ and 47.06 compared to plants under the strategy NS. In the present study, stomatal closure occurred due to the osmotic conditioning exerted by the highest level of irrigation water salinity $\left(4.0 \mathrm{dS} \mathrm{m}^{-1}\right)$, which may be directly linked to stomatal conductance, which decreased in a similar manner. Therefore, using water of highest electrical conductivity decreased $g s$ in watermelon plants through the reduction in soil osmotic potential and, consequently, in the water potential. According to Leite et al. (2017), irrigation water salinity makes it difficult for plants to absorb water from the soil, so they reduce water loss and a reduction occurs in stomatal conductance.

Salinity management strategies also influenced watermelon $\mathrm{CO}_{2}$ assimilation rate. According to the means comparison test (Fig 1C), plants under the strategies NS, VE, VE/FL, FL and MAT showed the highest mean values of $A$, of the order of $17.91,18.46,16.28,16.87$ and $16.69 \mu \mathrm{mol} \mathrm{m} \mathrm{m}^{-2} \mathrm{~s}^{-1}$, respectively. Conversely, the strategies FL/FR, FR and FR/MAT led to the lowest mean values of $A$, of the order of 10.94, 9.36 and $9.70 \mu \mathrm{mol} \mathrm{m} \mathrm{m}^{-2} \mathrm{~s}^{-1}$, which represented reductions of $38.92,47.74$ and $45.85 \%$ compared to the strategy NS. The reduction in watermelon $\mathrm{CO}_{2}$ assimilation rate is a consequence of the decrease observed previously in $E$ and $g s . \mathrm{CO}_{2}$ influx occurs through the stomata in the photosynthetic process, also resulting in water efflux, through transpiration, and stomatal movement is the main mechanism of gas exchange control in plants. Under salt stress, there may be a reduction in soil osmotic potential, which may lead to water stress conditions and possibly cause nutritional imbalance. This results in a reduction in the absorption and transport of nutrients in the plant, due to the quantity of excess ions in soil, consequently leading to reduction in $A$, due to the reductions of $E$ and $g s$, decreasing $\mathrm{CO}_{2}$ availability. Therefore, due to the reduction in water 
Table 1. Summary of analysis of variance for transpiration $(E)$, stomatal conductance $(g s), \mathrm{CO}_{2}$ assimilation rate $(A)$, instantaneous water use efficiency (WUEi), instantaneous carboxylation efficiency (CEi), the relative growth rates of main branch length (RGR mbl ) and stem diameter $\left(R_{\mathrm{G}} \mathrm{R}_{\mathrm{sd}}\right)$ and absolute growth rates of main branch length $\left(A G R_{\mathrm{mbl}}\right)$ and stem diameter $\left(A G R_{s d}\right)$ in 'Sugar Baby' watermelon grown under salinity management strategies (SMS) and potassium doses (KD).

\begin{tabular}{|c|c|c|c|c|c|c|c|c|c|c|c|}
\hline \multirow[b]{2}{*}{ SV } & \multirow[b]{2}{*}{ DF } & \multicolumn{10}{|c|}{ Mean square } \\
\hline & & $E$ & gs & $A$ & $\mathrm{Ci}$ & WUEi & CEi & $\mathrm{RGR}_{\mathrm{mbl}}$ & $\mathrm{RGR}_{\mathrm{sd}}$ & $A G R_{\mathrm{mbl}}$ & $\mathrm{AGR}_{\mathrm{sd}}$ \\
\hline SMS & 7 & $1.86^{* *}$ & $0.0100^{* *}$ & $134.1^{* *}$ & $855.4^{\mathrm{ns}}$ & $37.9^{\text {ns }}$ & $0.0073^{* *}$ & $0.000073^{\text {ns }}$ & $0.000074^{* *}$ & $0.24^{\text {ns }}$ & $0.00140^{* *}$ \\
\hline KD & 2 & $0.07^{\mathrm{ns}}$ & $0.0001^{\mathrm{ns}}$ & $6.9^{\mathrm{ns}}$ & $1282.6^{\mathrm{ns}}$ & $23.1^{\mathrm{ns}}$ & $0.0006^{\mathrm{ns}}$ & $0.000026^{\mathrm{ns}}$ & $0.000004^{\mathrm{ns}}$ & $0.05^{\mathrm{ns}}$ & $0.000030^{\text {ns }}$ \\
\hline SMSXKD & 14 & $0.11^{\mathrm{ns}}$ & $0.0003^{\mathrm{ns}}$ & $5.2^{\mathrm{ns}}$ & $1071.1^{\mathrm{ns}}$ & $37.8^{\mathrm{ns}}$ & $0.0006^{\mathrm{ns}}$ & $0.000093^{\mathrm{ns}}$ & $0.000009^{\mathrm{ns}}$ & $0.48^{\mathrm{ns}}$ & $0.00025^{\mathrm{ns}}$ \\
\hline Blocks & 2 & $1.96^{* *}$ & $0.0021^{\mathrm{ns}}$ & $17.4^{\mathrm{ns}}$ & $21406.0^{* *}$ & $34.5^{\text {ns }}$ & $0.0126^{* *}$ & $0.000001^{\mathrm{ns}}$ & $0.000004^{\mathrm{ns}}$ & $0.18^{\mathrm{ns}}$ & $0.00018^{\mathrm{ns}}$ \\
\hline Residual & 46 & 0.22 & 0.0012 & 9.1 & 1059.7 & 32.0 & 0.0009 & 0.000142 & 0.000011 & 0.4622 & 0.00021 \\
\hline Mean & & 2.2 & 0.1400 & 14.5600 & 169.7777 & 6.9 & 0.09 & 0.04 & 0.01 & 4.11 & 0.05 \\
\hline CV(\%) & & 20.9 & 24.8 & 20.8 & 19.1 & 81.5 & 33.6 & 26.56 & 30.03 & 16.59 & 28.93 \\
\hline
\end{tabular}

$\mathrm{SV}=$ Source of variation; SMS = Salinity management strategies; KD = Potassium doses; DF = Degrees of freedom; CV $(\%)$ = Coefficient of variation; **significant at 0.01 probability level.
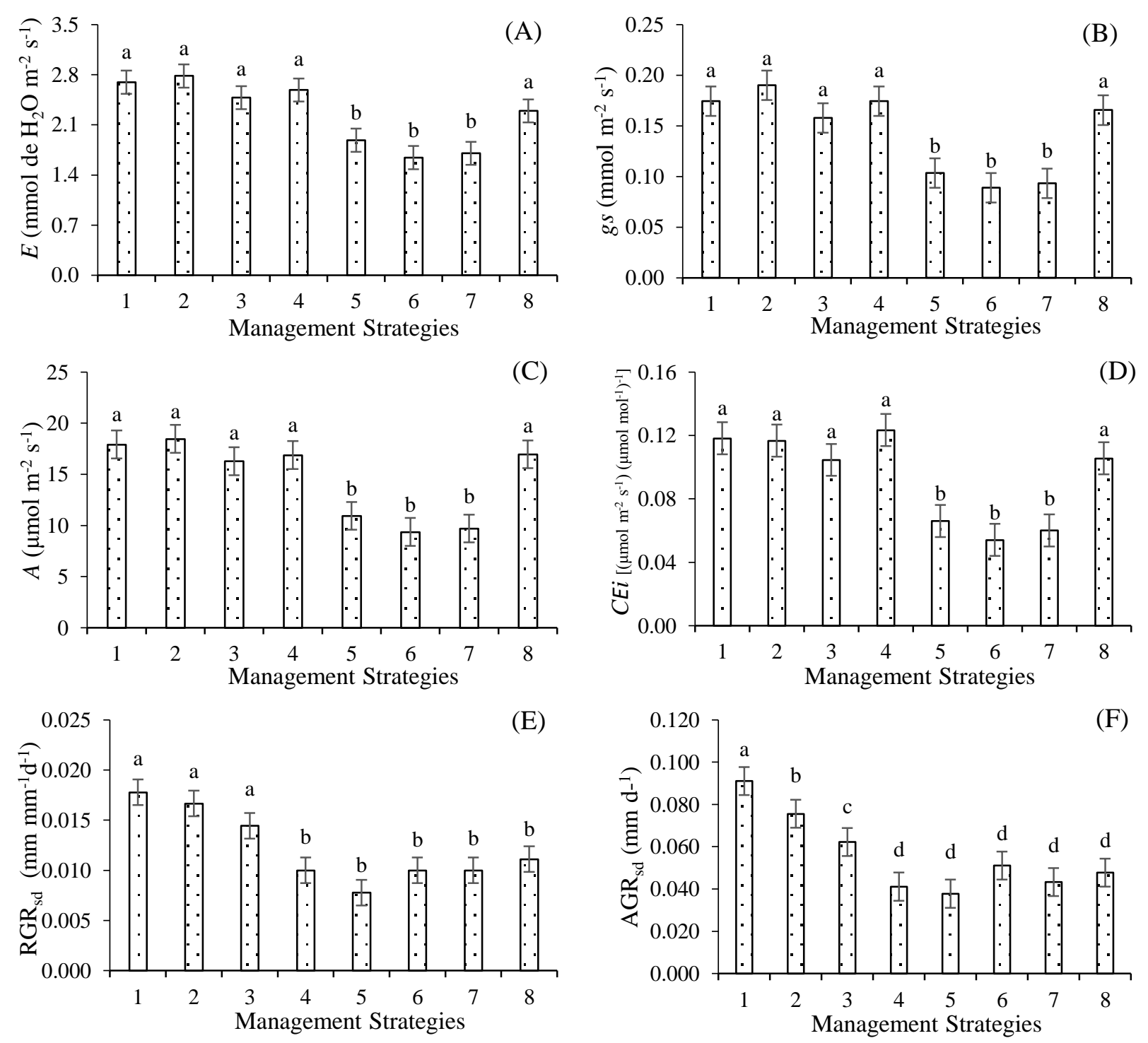

Fig 1. Transpiration $-E(A)$, stomatal conductance $-g s(B), \mathrm{CO}_{2}$ assimilation rate $-A(C)$, instantaneous carboxylation efficiency $-C E i$ (D), relative growth rate of stem diameter - RGRsd (E) and absolute growth rate of stem diameter - AGRsd (F) in 'Sugar Baby' watermelon, as a function of salinity management strategies. Means with different letters indicate that the treatments differed by Scott-Knott test, $p<0.05 .1 \mathrm{NS}=$ no stress along the cycle; $2 \mathrm{VE}=$ salt stress at vegetative stage; $3 \mathrm{VE} / \mathrm{FL}=$ salt stress during vegetative and flowering stages; $4 \mathrm{FL}=$ salt stress during flowering stage; $5 \mathrm{FL} / \mathrm{FR}=$ salt stress during flowering and fruiting stages; 6 $\mathrm{FR}=$ salt stress during fruiting stage; $7 \mathrm{FR} / \mathrm{MAT}=$ salt stress during fruiting and maturation stages; $8 \mathrm{MAT}=$ salt stress during fruit maturation stage. 
Table 2. Chemical characteristics of the soil used in the experiment, before applying the treatments.

Chemical characteristics

\begin{tabular}{|c|c|c|c|c|c|c|c|c|c|}
\hline \multirow{2}{*}{$\begin{array}{l}\mathrm{pH}\left(\mathrm{H}_{2} \mathrm{O}\right) \\
(1: 2.5)\end{array}$} & \multirow{2}{*}{$\begin{array}{l}\text { OM } \\
\text { dag kg }^{-1}\end{array}$} & \multirow{2}{*}{$\begin{array}{l}\mathrm{P} \\
\left(\mathrm{mg} \mathrm{kg}^{-1}\right)\end{array}$} & $\mathrm{K}^{+}$ & $\mathrm{Na}^{+}$ & $\mathrm{Ca}^{2+}$ & $\mathrm{Mg}^{2+}$ & $\mathrm{Al}^{3+}+\mathrm{H}^{+}$ & \multirow{2}{*}{$\begin{array}{l}\text { PST } \\
(\%)\end{array}$} & \multirow{2}{*}{$\begin{array}{l}\mathrm{EC}_{\mathrm{se}} \\
\left(\mathrm{dS} \mathrm{\textrm {m } ^ { - 1 }}\right)\end{array}$} \\
\hline & & & \multicolumn{5}{|c|}{ 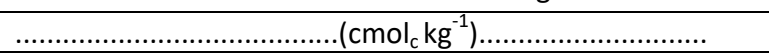 } & & \\
\hline 5.90 & 1.36 & 6.8 & 0.22 & 0.16 & 2.60 & 3.66 & 1.93 & 0.67 & 0.19 \\
\hline \multicolumn{10}{|c|}{ Physical characteristics } \\
\hline \multicolumn{3}{|c|}{ Size fraction $\left(\mathrm{g} \mathrm{kg}^{-1}\right)$} & \multirow{2}{*}{$\begin{array}{l}\text { Textural } \\
\text { class }\end{array}$} & \multicolumn{2}{|c|}{ Water content $(\mathrm{kPa})^{*}$} & \multirow[b]{2}{*}{$\ldots \ldots \ldots \ldots$} & \multirow{2}{*}{$\begin{array}{l}\text { Total } \\
\text { porosity } \\
\left(\mathrm{m}^{3} \mathrm{~m}^{-3}\right)\end{array}$} & $\mathrm{BD}$ & \multirow[t]{2}{*}{ PD } \\
\hline Sand & Silt & Clay & & 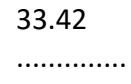 & $\begin{array}{l}1519.5 \\
\text { dag kg }^{-1}\end{array}$ & & & $\left(\mathrm{~kg} \mathrm{dm}^{-3}\right)$ & \\
\hline 732.9 & 142.1 & 125.0 & SL & 11.98 & 4.32 & 7.36 & 47.74 & 1.39 & 2.66 \\
\hline
\end{tabular}

availability in soil, caused by the decrease in osmotic potential, stomatal closure may occur, limiting transpiration, which consequently reduces the photosynthetic rate (Silva et al., 2010).

The instantaneous carboxylation efficiency was significantly influenced by the salinity management strategies and, according to the means comparison test (Fig 1D), plants under the strategies NS, VE, VE/FL, FL and MAT obtained the highest mean values of $C E i$, of the order of $0.12,0.12,0.10$, 0.12 and $\left.\left.0.11\left[\left(\mu \mathrm{mol} \mathrm{m} \mathrm{m}^{-2} \mathrm{~s}^{-1}\right)(\mu \mathrm{mol} \mathrm{mol})^{-1}\right)^{-1}\right]\right)$. By contrast plants subjected to the strategies FL/FR, FR and FR/MAT had the lowest mean values of $C E i$, of the order of $0.07,0.05$ and $\left.0.06\left[\left(\mu \mathrm{mol} \mathrm{m} \mathrm{s}^{-1}\right)(\mu \mathrm{mol} \mathrm{mol})^{-1}\right)^{-1}\right]$, respectively, which were equivalent to reductions of $41.67,58.33$ and $50.00 \%$ compared to those under the strategy NS, which were irrigated with low-salinity water $\left(0.8 \mathrm{dS} \mathrm{m}^{-1}\right)$ throughout the entire experiment. The decrease in instantaneous carboxylation efficiency may be related to the reductions in both stomatal conductance and $\mathrm{CO}_{2}$ assimilation rate, due to salt stress, which may have compromised stomatal activity, for increasing the resistance to $\mathrm{CO}_{2}$ diffusion. Additionally, the salt stress imposed on these plants may have damaged the metabolism of leaf mesophyll cells, which may restrict photosynthesis, consequently compromising CEi. According to Taiz and Zeiger (2013), depending on the stress severity level, the dehydration of mesophyll cells inhibits photosynthesis, the mesophyll metabolism is damaged and, consequently, carboxylation efficiency is compromised.

\section{Effect of salinity management strategies and potassium fertilization on watermelon growth parameters}

The growth parameters evaluated in watermelon (RGRsd and AGRsd) were significantly affected by the salinity management strategies (Table 1). Neither $\mathrm{K}$ doses nor their interaction with salinity management strategies caused significant effect $(p>0.05)$ on the growth of 'Sugar Baby' watermelon in the period from 27 to 65 days after sowing. According to the results of the means grouping test (Fig 1E), there was a significant response to the salinity management strategies for the relative growth rate of stem diameter. Plants cultivated under the strategy of NS obtained the highest mean value, of the order of $0.018 \mathrm{~mm} \mathrm{~mm}^{-1} \mathrm{~d}^{-1}$, followed by VE $\left(0.017 \mathrm{~mm} \mathrm{~mm}^{-1} \mathrm{~d}^{-1}\right)$ and VE/FL $(0.014 \mathrm{~mm}$ $\mathrm{mm}^{-1} \cdot \mathrm{d}^{-1}$ ) with the second and third highest mean values of RGRsd, respectively. On the other hand, plants under the strategies $\mathrm{FL}, \mathrm{FL} / \mathrm{FR}, \mathrm{FR}, \mathrm{FR} / \mathrm{MAT}$ and MAT had the lowest mean values of RGRsd, of the order of $0.010,0.008,0.010$,
0.010 and $0.011 \mathrm{~mm} \mathrm{~mm}^{-1} \mathrm{~d}^{-1}$, respectively. Excess salts in soil lead to decrease in the osmotic potential of the soil solution, and the time of exposure to salt stress decisively contributed to the reduction in plant growth. In addition, salt stress may have caused nutritional imbalance, through the accumulation of ions in plant tissues. Moreover, when exposed to salt stress, plants may undergo a reduction in meristematic activity and cell elongation, besides functional disorders and damage in their metabolism (Munns \& Tester, 2008; Silva et al., 2010), consequently leading to reduction in growth rate.

Salinity management strategies caused a significant effect on AGRsd and, according to the means grouping test (Fig 1F), plants under the strategy NS had the highest mean values, on the order of $0.091 \mathrm{~mm} \mathrm{~d}^{-1}$, followed by the strategies $V E$ $\left(0.076 \mathrm{~mm} \mathrm{~d}^{-1}\right)$ and VE/FL $\left(0.062 \mathrm{~mm} \mathrm{~d}^{-1}\right)$ with the second and third highest mean values of AGRsd, respectively. By contrast, the strategies of $\mathrm{FL}, \mathrm{FL} / \mathrm{FR}, \mathrm{FR}, \mathrm{FR} / \mathrm{MAT}$ and MAT led to the lowest mean values of AGRsd, of the order of $0.041,0.038,0.051,0.043$ and $0.048 \mathrm{~mm} \mathrm{~d}^{-1}$, respectively. The successive salt stress imposed at the phenological stages of flowering, fruiting and maturation influenced the reduction in watermelon stem diameter. Due to the time of exposure to the salt stress, plants had lower capacity to retain and absorb water, due to the reduction in the osmotic potential. In addition, stomatal closure and the reductions in gas exchanges may also have influenced the reduction in AGRsd. Decrease in stem growth under saline conditions can be associated with the reduction of photosynthesis (Munns and Tester, 2008). According to Silva et al. (2011), prolonged exposure to the salts leads to alterations in the water conditions of plants, inducing stomatal closure and consequently limiting $\mathrm{CO}_{2}$ entry; in addition, high concentrations of ions such as $\mathrm{Na}^{+}$and $\mathrm{Cl}^{-}$damage the structures of enzymes and membranes, directly interfering with photosynthesis.

\section{Materials and methods}

Localization, experimental procedure, treatments and plant material

The experiment was conducted from October to December 2017, in a protected environment (greenhouse) at the Center of Technology and Natural Resources - CTRN of the Federal University of Campina Grande - UFCG, located in the municipality of Campina Grande, Paraíba, Brazil, at 
geographic coordinates $7^{\circ} 15^{\prime} 18^{\prime \prime} \mathrm{S}, 35^{\circ} 52^{\prime} 28^{\prime \prime} \mathrm{W}$ and average altitude of $550 \mathrm{~m}$.

The experimental design was randomized blocks, in $8 \times 3$ factorial arrangement, corresponding to eight water salinity management strategies and three doses of potassium, with three replicates, in a total of 72 experimental units. The salinity management strategies were applied at different development stages of the crop: NS = no stress along the cycle; $\mathrm{VE}=$ salt stress during vegetative stage; $\mathrm{VE} / \mathrm{FL}=$ salt stress during vegetative and flowering stages; $\mathrm{FL}=$ salt stress during flowering stage; $\mathrm{FL} / \mathrm{FR}=$ salt stress during flowering and fruiting stages; $F R=$ salt stress during fruiting stage; FR/MAT = salt stress during fruiting and maturation stages; MAT = salt stress during fruit maturation stage. The potassium doses used corresponded to 50,100 and $150 \%$ of the recommendation (150 mg K $\mathrm{K}_{2} \mathrm{O} \mathrm{kg}{ }^{-1}$ soil) for pot experiments (Novais et al., 1991), and were split into three portions applied via fertigation at 23,37 and 46 days after sowing (DAS).

Salinity management strategies were established using irrigation water of two levels of electrical conductivity (ECW), a low level $\left(E C w=0.8 \mathrm{dS} \mathrm{m}^{-1}\right)$ and a high level $(E C w=4.0 \mathrm{dS}$ $\left.\mathrm{m}^{-1}\right)$, and by varying the phenological stages: vegetative period from emergence of second true leaf to appearance of first female flower (14-34 DAS); flowering - period from appearance of first female flower to fruit setting (35-43 DAS); fruiting - period from fruit setting to fruit filling (44-58 DAS); and maturation - period from fruit filling to harvest (59-65 DAS).

The crop used was watermelon, cv. 'Sugar Baby', which has precocious cycle, with harvest from 75 days after planting. It is a rustic plant with vigorous foliage and tolerant to high temperatures. It has round fruits with dark-green rind, weighing around 2 to $4 \mathrm{~kg}$. Its pulp contains high sugar content, is soft and shows an intense red color (Souza et al., 2004; Silva et al., 2008).

\section{Establishment and management of the experiment}

Plastic containers with capacity for $20 \mathrm{~L}$ were adapted as lysimeters, receiving a $3-\mathrm{cm}$-thick layer of crushed stone at the base and a geotextile to avoid clogging by soil material. To allow drainage and determine water consumption by plants, a 4-mm-diameter transparent tube was connected to their bottom parts. Then, the containers received $24 \mathrm{~kg}$ of an Entisol collected in the $0-20 \mathrm{~cm}$ layer in cultivated area of the municipality of Lagoa Seca-PB. Its physical and chemical attributes (Table 2) were determined according to the methodology of Donagema et al. (2011).

Fertilizations with phosphorus and nitrogen were performed as recommended by Novais et al. (1991), applying via fertigation 300 and $100 \mathrm{mg} \mathrm{kg}^{-1}$ of soil of $\mathrm{P}_{2} \mathrm{O}_{5}$ and $\mathrm{N}$, respectively, using single superphosphate and calcium nitrate as sources, split into three portions. Phosphorus was applied at 15, 32 and 42 DAS, whereas nitrogen was applied at 19, 35 and 44 DAS. Micronutrients were applied at 27, 34, and 46 DAS.

Sowing was carried out by equidistantly planting 4 seeds at 3 $\mathrm{cm}$ depth. Prior to sowing, the soil was brought to the level corresponding to field capacity (FC) in all experimental units, using low-salinity water. After sowing, irrigations were performed daily at 17:00 h, applying in each container the volume corresponding to the water requirement of the plants, determined through the water balance, according to equation 1.
$\mathrm{VC}=\frac{\mathrm{VA}-\mathrm{VD}}{1-\mathrm{LF}}$

Where: $V C$ is the volume consumed $(L)$, considering the water volume (L) applied to plants (VA) on the previous day; $V D$ is the volume (L) drained, quantified in the morning of the following day; and LF is the desired leaching fraction, estimated as $10 \%$, to reduce the accumulation of salts in the root zone. At $14 \mathrm{DAS}$, when plants were established, the solutions of each treatment began to be applied in each container.

The lowest level of water salinity $\left(0.8 \mathrm{dS} \mathrm{m}^{-1}\right)$ was obtained by diluting water from the public supply system of Campina Grande in rainwater $\left(E C w=0.02 \mathrm{dS} \mathrm{m}^{-1}\right)$. The level corresponding to $\mathrm{ECW}$ of $4.0 \mathrm{dS} \mathrm{m}^{-1}$ was prepared in a way to have an equivalent proportion of 7:2:1 of $\mathrm{Na}: \mathrm{Ca}: \mathrm{Mg}$, respectively, which prevails frequently in the sources of water used for irrigation in small properties of Northeast Brazil. The solutions were prepared considering the relationship between $\mathrm{ECW}$ and the concentration of salts $\left(10^{*} \mathrm{mmol}_{\mathrm{c}} \mathrm{L}^{-1}=1 \mathrm{dS} \mathrm{m}^{-1}\right)$, described by Richards (1954).

Pests and diseases were controlled by chemical intervention, with preventive applications of insecticides from the Neonicotinoid chemical group (soluble powder) and fungicide from the Dicarboximide chemical group (soluble powder), whereas invasive plants in the lysimeters were controlled by manual weeding. Watermelon plants were vertically grown using stakes and each one had one main branch and three lateral branches. Pollination was artificially performed, using a swab to collect pollen and take it to the stigma, always between 06:00 to 07:00 A.M., leaving only one fruit per plant.

\section{Traits measured}

Physiological parameters were measured at the fruiting stage (55 DAS) based on stomatal conductance $(\mathrm{gs})\left(\mathrm{mol} \mathrm{m}^{-2}\right.$

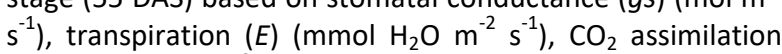
rate $(A)\left(\mu \mathrm{mol} \mathrm{m} \mathrm{m}^{-1}\right)$ and internal $\mathrm{CO}_{2}$ concentration $(\mathrm{Ci})$ $\left(\mu \mathrm{mol} \mathrm{mol}^{-1}\right)$. These data were used to estimate instantaneous water use efficiency (WUEi) $(A / E)\left[\left(\mu \mathrm{mol} \mathrm{m} \mathrm{m}^{-2}\right.\right.$ $\left.\mathrm{s}^{-1}\right)\left(\mathrm{mmol} \mathrm{H} \mathrm{O} \mathrm{m}^{-2} \mathrm{~s}^{-1}\right)^{-1}$ ] and instantaneous carboxylation efficiency (CEi) $\left.(A / C i)\left[\left(\mu \mathrm{mol} \mathrm{m} \mathrm{s}^{-1}\right)(\mu \mathrm{mol} \mathrm{mo})^{-1}\right)^{-1}\right]$ under photosynthetic photons flux of $1,200 \mu \mathrm{mol} \mathrm{m} \mathrm{m}^{-2} \mathrm{~s}^{-1}$. These measurements were taken using a gas exchange meter, containing an Infrared Gas Analyzer - IRGA (LCpro - SD model, ADC Bioscientific, UK).

At the beginning and end of each stage (27 to 65 DAS), watermelon plants were measured for main branch length $(\mathrm{MBL})$, stem diameter (SD) and number of leaves (NL). These data were then used to determine the relative growth rate (RGR) and absolute growth rate (AGR) according to equations 2 and 3 (Benincasa, 2003):

$\mathrm{RGR}=\frac{(\operatorname{InA} 2-\operatorname{In} \mathrm{A} 1)}{(\mathrm{t} 2-\mathrm{t} 1)}$

$\mathrm{AGR}=\frac{(\mathrm{A} 2-\mathrm{A} 1)}{(\mathrm{t} 2-\mathrm{t} 1)}$

Where: $A_{2}=$ main branch length or stem diameter obtained at the end of the studied period; $A_{1}=$ main branch length or stem diameter obtained at the beginning of the studied period; $t_{2}-t_{1}=$ time difference between the measurements.

\section{Statistical analysis}

The obtained data were subjected to analysis of variance by $F$ test. In cases of significance, Scott-Knott means grouping test $(p<0.05)$ was carried out for salinity management 
strategies, whereas Tukey test $(p<0.05)$ was conducted for potassium doses, using the program Sisvar (Ferreira, 2011).

\section{Conclusions}

The gas exchanges and growth, especially transpiration, stomatal conductance, $\mathrm{CO}_{2}$ assimilation rate, instantaneous carboxylation efficiency, relative growth rate of stem diameter and absolute growth rate of stem diameter of 'Sugar Baby' watermelon, are compromised by irrigation water salinity applied at the stages of flowering, fruiting and maturation. Potassium doses and their interaction with the management strategies of irrigation water salinity did not affect the gas exchanges and growth of 'Sugar Baby' watermelon.

\section{Acknowledgements}

The Coordination for the Improvement of Higher Education Personnel (CAPES) for granting scholarship to the first author and to the National Institute of Science and Technology in Salinity - INCTSal, for funding the project.

\section{References}

Andrade EMG, Lima GS de, Lima VLA de, Gheyi HR, Silva AAR da, Fernandes PD, Souza L de P, Silva SS da (2018) Physiology and growth of cashew 'Anão precoce' (Anacardium occidentale L.) subjected to salt stress and organic fertilization. Aust J Crop Sci. 12:1150-1158.

Araújo HS, Quadros BR de, Cardoso All, Corrêa CV (2012) Doses de potássio em cobertura na cultura da abóbora. Pesq Agropecu Trop. 42:469-475.

Ayers RS, Westcot DN (1999) A qualidade da água na agricultura. 2. ed. Campina Grande: UFPB. 153 p. (Estudos FAO, Irrigação e drenagem, 29 revisado 1).

Benincasa MMP (2003) Análise de crescimento de plantas, noções básicas. 2. ed. Jaboticabal: FUNEP. 41p.

Calvet ASF, Pinto C de M, Lima REM, Maia-Joca RPM, Bezerra MA (2013) Crescimento e acumulação de solutos em feijão-de-corda irrigado com águas de salinidade crescente em diferentes fases de desenvolvimento. Irriga. 18:148159.

Costa ARC, Medeiros JF, Porto Filho FQ, Silva JS, Costa FGB, Freitas DC (2013) Produção e qualidade de melancia cultivada com água de diferentes salinidades e doses de nitrogênio. Rev Bras Eng Agríc Ambient. 17:947-954.

Dias N da S, Oliveira AM de, Sousa Neto ON de, Blanco FF, Rebouças JRL (2011) Concentração salina e fases de exposição à salinidade do meloeiro cultivado em substrato de fibra de coco. Rev Bras Frutic. 33:915-921.

Donagema GK, Campos DV B de, Calderano SB, Teixeira WG, Viana JHM (2011). Manual de métodos de análise de solos. 2.ed. rev. Rio de Janeiro: Embrapa Solos. 230 p. (Embrapa Solos. Documentos, 132).

Dong H (2012) Technology and field management for controlling soil salinity effects on cotton. Aust J Crop Sci. 6:333-341.

Ferreira DF (2011) Sisvar: a computer statistical analysis system. Ciênc Agrotec. 35:1039-1042.

Figueirêdo VB, Medeiros JF, Zocoler JL, Espindola Sobrinho J (2009) Evapotranspiração da cultura da melancia irrigada com água de diferentes salinidades. Eng Agríc. 29:231-240.

Furtado GF, Pereira FHF, Andrade EMG, Pereira Filho RR, Silva SS (2012) Efeito do nitrato de cálcio na redução do estresse salino em melancieira. Rev Verde de Agroec e Desenvolv Sustent. 7:33-40.

Guedes RAA, Oliveira F de A de, Alves R de C, Medeiros AS de, Gomes LP, Costa LP (2015) Estratégias de irrigação com água salina no tomateiro cereja em ambiente protegido Rev Bras Eng Agríc Ambient. 19:913-919.

Hawkesford M, Horst W, KIchey T, Schjoerring J, Moller I S, White $P$ (2012) Functions of macronutrients. In: Marschner $P$ (ed.). Mineral nutrition of higher plants. 3. ed., New York: Elsevier. p.135-189.

Hoffman GJ, Shalhevet J (2007) Controlling salinity. In: Hoffman GJ, Evans RG, Jensen ME, Martin DL, Elliott RL. Design and operation of farm irrigation systems, 2 . ed. St Joseph: American Society of Agricultural and Biological Engineers. p.160-207.

Lacerda CF de, Costa RNT, Bezerra MA, Neves ALR, Sousa GG de, Gheyi HR (2016) Estratégias de manejo para uso de água salina na agricultura. In: Gheyi HR, Dias $\mathrm{N}$ da $\mathrm{S}$, Lacerda CF de, Gomes Filho E (ed) Manejo da salinidade na agricultura: estudos básicos e aplicados. 2.ed. Fortaleza: INCTSal. p. 337-352.

Lacerda CF, Silva FB, Neves ALR, Silva FLB, Gheyi HR, Ness RLL, Gomes Filho E (2011) Influence of plant spacing and irrigation water quality on a cowpea-maize cropping system. Int Res J Agric Sci Soil Sci. 1:163-167.

Langer K, Levchenko V, Fromm J, Geiger D, Steinmeyer R, Lautner S, Ache P, Hedrich R (2004) The poplar K ${ }^{+}$channel KPT1 is associated with $\mathrm{K}^{+}$uptake during stomatal opening and bud development. Plant J. 37:828-838.

Leite JVQ, Fernandes PD, Oliveira WJ, Souza ER, Santos DP, Santos CS (2017) Efeito do estresse salino e da composição iônica da água de irrigação sobre variáveis morfofisiológicas do feijão-caupi. Rev Bras Agric Irr. 11:1825-1833.

Mesquita FO, Nunes JC, Limaneto AJ, Souto AGL, Batista RO, Cavalcante LF (2015) Formação de mudas de nim sob salinidade da água, biofertilizante e drenagem do solo. Irriga. 20:193-203.

Moreira FJC, Valnir Junior M, Araújo OP, Luna N de S, Sales L de $S$ (2015) Fenologia e produtividade da melancia no semiárido cearense, com kit de irrigação desenvolvido para a agricultura familiar. Cad Cult Cien. 14:24-42.

Munns R, Tester M (2008) Mechanism of salinity tolerance. Annu Rev Plant Biol. 59:651-681.

Murtaza G, Ghafoor A, Qadir M (2006) Irrigation and soil management strategies for using saline-sodic water in a cotton-wheat rotation. Agr Water Manage. 81:98-114.

Neves ALR, Lacerda CF, Guimarães FVA, Hernandez FFF, Silva FB, Prisco JT, Gheyi HR (2009) Acumulação de biomassa e extração de nutrientes por plantas de feijão-de-corda irrigadas com água salina em diferentes estádios de desenvolvimento. Cienc Rural. 39:758-765.

Novais RF, Neves JCL, Barros NF (1991) Ensaio em ambiente controlado. In: Oliveira AJ Garrido WE, Araújo JD de, Lourenço $S$ (ed.) Métodos de pesquisa em fertilidade do solo. Embrapa-SEA, Brasília, Brasil. p.189-253.

Petry JF, Guimarães MA (2013) O cultivo da melancia no Brasil em números. In: Guimarães MA. Produção de melancia. Editora UFV, Viçosa. p. 27-43.

Queiroz JE, Gonçalves ACA, Solto JS, Folegatti M, Souza ER de, Barros M de FC (2016) Avaliação e monitoramento da salinidade do solo usando ferramentas de geoestatística. In: Gheyi HR, Dias NS, Lacerda CF, Gomes Filho E (ed) Manejo da salinidade na agricultura: estudos básicos e aplicados. 2.ed. Fortaleza: INCTSal. p.51-63. 
Richards LA (1954) Diagnosis and improvement of saline and alkali soils. Washington: U. S. Department of Agriculture. 160p. Handbook 60.

Santos DB dos, Ferreira PA, Oliveira FG, Garcia GO, Carneiro JE de S, Cano MAO (2005) Estratégias de manejo da irrigação do feijoeiro com água salina. Rev Bras Eng Agríc Ambient. 9:16-20.

Shimazaki K, Doi M, Assmann SM, Kinoshita T (2007) Light regulation of stomatal movement. Annu Rev Plant Biol. 58:219-247.

Silva CDS, Santos PAA, Lira JMS, Santana MC, Silva Junior CD (2010) Curso diário das trocas gasosas em plantas de feijão-caupi submetidas à deficiência hídrica. Rev Caatinga. 23:7-13.

Silva EN, Ribeiro RV, Ferreira-Silva SL, Viégas RA, Silveira JAG (2010) Comparative effects of salinity and water stress on photosynthesis, water relations and growth of Jatropha plants. J Arid Environ. 74:1130-1137.

Silva EN da, Ribeiro RV, Ferreira-Silva SL, Viégas RA, Silveira JAG (2011) Salt stress induced damages on the photosynthesis of physic nut young plants. Sci Agric. 68:6268.
Silva JR da, Nunes GH de S, Negreiros MZ de, Torres JF, Dantas MSM (2008) Interação genótipo $\mathrm{x}$ ambiente em melancia no Estado do Rio Grande do Norte. Rev Caatinga. 21:95-100.

Soares LA dos A, Fernandes PD, Lima GS de, Suassuna JF, Brito MEB, Sá FV da S (2018) Growth and fiber quality of colored cotton under salinity management strategies. Rev Bras Eng Agríc Ambient. 22:332-337.

Souza FF, Gama FC, Queiróz MA (2004) Análise da capacidade de combinação em cruzamentos dialélicos de três genótipos de melancia. Hortic Bras. 22:789-793.

Taiz L, Zeiger E, Møller IM, Murphy A (2017) Fisiologia e desenvolvimento vegetal. 6.ed. Porto Alegre: Artmed. $918 p$.

Terceiro Neto CPC, Medeiros JF de, Gheyi HR, Dias N da S, Oliveira, FRA de, Lima K da S (2012) Acúmulo de matéria seca e nutrientes no meloeiro irrigado sob estratégias de manejo da salinidade. Rev Bras Eng Agríc Ambient. 16:1069-1077.

Vidigal SM, Pacheco DD, Costa EL, Facion CE (2009) Crescimento e acúmulo de macronutrientes pela melancia em solo arenoso. Rev Ceres. 56:112-118.

Zörb C, Senbayram M, Peiter E (2014) Potassium na agricultura: status e perspectivas. J Plant Physiol. 171:656669. 